\title{
Determinants of cattle Market Participation Decision by Pastoralist in Southern Ethiopia: The case of Moyale district in Borana zone of Oromiya Region
}

\author{
Zekarias Bassa $^{1 *}$ and Teshale Woldeamanuel ${ }^{2}$ \\ ${ }^{1}$ School of Natural Resource and Environmental Studies, Hawassa University, Ethiopia \\ ${ }^{2}$ Southern Agricultural Research Institute, Areka Agricultural Research Center, Ethiopia
}

Submission: July 09, 2018; Published: August 01, 2018

*Corresponding author: Zekarias Bassa, School of Natural Resource and Environmental Studies, Wondogenet College of Forestry and Natural Resource, Hawassa University, P.O. Box 125, Wondogenet, Ethiopia. Tel : 251913918474, Email: bassazekarias@yahoo.com

\begin{abstract}
The logistic regression analysis was employed to identify determinants of cattle market participation decision by pastoral household in Borana zone. Three kebeles were selected based on secondary data and reviewed literatures. Primary data were collected from 223 sampled pastoralist, 25 traders and 14 brokers. Econometric Approach was used to investigate determinants of pastoralist household cattle market participation. For logistic regression model six explanatory variables used and out of which three significantly affect probability of producers' market participation decision. The number of cattle owned, number of camel owned and gender are predictors that significantly affect probability of cattle market participation. Both number of cattle and camel owned per household affects positively the probability of market participation. This implies that rearing large size of cattle and camels provoke cattle market participation decision of pastorals and it is also advisable to promote Borana cattle breed conservation. Holding the other predictor variables constant, being male by its-self increase the probability cattle market participation by 2.92 factors as compared to female household heads. This calls for systematic intervention of government to mainstreaming gender in cattle market that supposed to optimize the sector productivity. For one unit increase in number of cattle owned the probability of cattle market participation increase by 1.12 factors, other factors held fixed. For one unit increase in number of camel owned, the probability of cattle market participation decision increase by factor of 1.23 times, given the other variables held constant. Top 1st to 5 th ranked constraints of cattle market include lengthy market, brokers' interference, disease and parasite, clan conflict and unfriendly relation between market actors. Other 6th to 10th ranked market problems include informal trade, lack of reliable market information, recurrent tax, infrastructure constraint and initial capital problem. As remedial measure shortening the supply chain, animal health center development, capacity development, adopting value addition practices, update market information provision, cooperative formation and linking producers to market is believed to optimize the benefits of pastorals and boost cattle productivity.
\end{abstract}

Keywords: Client Satisfaction; Solid Waste Management; Waste Collection Frequency; Jimma city

\section{Introduction}

The greater cattle holdings results in greater cattle market participation and the greater capacity of willingness to sell animals. The key practical implication is that active livestock markets depend on pastoralists maintaining sufficiently large herd sizes that they become willing to liquidate animals through the market. It is generally believed that pastoralists sell their animals at least partly in response to demand for cash to meet expenditure needs. Relatively wealthy pastoralists, with greater herd size, have considerably higher expenditure rates and thus use livestock markets more frequently to cash out animals (Barrett et al. [1]). The cattle markets in most parts of the country are characterized by seasonality in flow and prices of animals. In the pastoral lowland areas major factors contribute to seasonal flow include festivals, weather, pasture, seasonality of consumption demand (fasting and ceremonial period) in domestic, drought, disease outbreak, lack of information, availability of food aid and clan conflicts (Getachew et al. [2] Awur [3]. The average cattle off-take rate is found to be well below $10 \%$ in Borana area of which only $11 \%$ household off-take decisions were made for financing non-pastoral business. Cattle off-take decisions are largely determined the need to procure cereal grains, meeting other needs and income diversity (Wassie and Bichaka [4]. The off take rates for livestock during drought were estimated to be about twofold than the off take rates during a normal year. The incremental off take rate during drought was 50 percent for cattle, 52 percent for sheep, 70 percent for goats, 11 percent for camels, and 11 percent for equines Awuor [3]. The distribution of the markets across the woredas in Borana zone does not conform to the size of cattle available in the area. Except the market at Moyale which sets up every day but Sunday, the rest of the markets in the area meet 1 to 2 days per week. This is a good opportunity for all market participants particularly 
for traders to take advantage of all the markets the whole week and fulfill their requirements (Getachew et al. [2]). Moyale and Mandera are the two largest cross-border terminal markets for livestock between Ethiopia and Kenya. Between 70-80 percent of live animals sold in these two markets originate in Ethiopia. The Ethiopia/Kenya livestock trade is very important because it links prime cattle production areas of southern Ethiopia to the region's largest market in Nairobi, Kenya (Awur [3]).

\section{General Objective}

a. To investigate relative factors of pastoralist household choice of cattle market participation

\section{Specific objectives}

a) To investigate determinants of pastoralist cattle market participation in Borana area.

b) To overview marketing level of cattle in different marketing seasons

c) To characterize major constraints of cattle marketing in the study district

\section{Methodology}

\section{The study area}

The Borena administrative zone is situated in Ethiopia's Oromia regional state at about $570 \mathrm{~km}$ (Yabalo town) from Addis Ababa (Niguse [5]). The Borana zone is made up of 13 districts, divided between two agro-ecological zones, the semiarid lowlands to the south and the more humid lands at higher altitudes to the north (Beyene and Yibeltal [6]).

\section{Livestock population of Borena Zone}

The population of livestock in Borana Zone, Oromiya Region was estimated to be 1,048,909 cattle, 396,819 sheep, 989,691 goats and 62,789 camels (CSA [7]. The livestock population of Moyale Woreda was estimated to be 52,280 cattle, 58,860 goat, 14,095 sheep, 17,185 camel, 4626 donkey, 21 mule, 3 horse and 17606 poultry Moyale Woreda Pastoralist Development office [8].

\section{Methods of Data Collection}

In this study both secondary and primary data was obtained from different sources. Journals, books, proceedings, CSA, and internet browsing were secondary data sources that used in the study. Primary data sources include Pastoral household interview, traders interview, brokers interview and key informant interview. A preliminary assessment was conducted to collect basic information about the woreda in order to select representative kebeles and the major cattle marketing centers. Structured and semi structured questionnaires was prepared and pre-tested for households interviewed. Key informants interview and household interview were employed for the study. Using the questionnaire, interviews was conducted to gather data on household characteristics, socioeconomic and demographic characteristics, and other sources of income, marketing period, months and seasons, marketing and challenges and threats of cattle trading.

\section{Sampling Techniques and sample size}

For this particular study a two stagesampling techniques was used. The main sampling techniques used for this study were probability and non probability sampling. Factors like percentage of pastoral population of the districts, number of livestock kept/income difference, age of pastoralists, major function of actors in cattle marketing: supplier, buyer, traders, middlemen and broker, proximity to major marketing centers, number of pastoral Peasant associations and cultural issues were important issued while selecting the representative households in the districts. The producers interviewed in the study were pastoralists. The random probability sampling techniques was used for selecting the representative households from the area. Two stages sampling technique was used for selection of pastoralists Kebele identification that made through secondary data of pastoralists development office, proximity to marketing centers, gender, ownership of cattle and other important economic variables. The random probability sampling techniques was used for selecting the representative producers. Two stages sampling technique was used for selection of pastoralists Kebele identification that made through secondary data of pastoralists development office. Three Kebeles from the pastoralist area were considered in the survey. Respondent sample size per each Kebele was determined proportionally to the number of total household in the area. The sample size determination techniques employed was Rule of Thumb Techniques that estimate by using the following formula: $100 \%$ for $0-100$ populations, $10 \%$ for $101-1,000$ populations, $5 \%$ for $1,001-5,000$ poulations, $3 \%$ for $5,001-10,000$ population and $1 \%$ for more than 10,000 respectively (Yount [9]). Based on this technique the sample size of pastoralists household interviewed from respective kebels, Maddo, Mado Miggo and Laga Sure were 100,63 and 60 respectively. The survey study at woreda level considered 167 male (74.9\%) and 56(25.1) female household heads. The sample size of male and female household heads interviewed in Maddo kebele was 78(78\%) and 22(22\%). The number male and female respondents interviewed in Laga Sure kebele was $45(75 \%)$ and 15(25\%). From whole interviewed respondents in Mado Migo Kebele, 44 (69.8\%) was male and 19 female $(30.2 \%)$.

\section{Method of Data Analysis: Descriptive and Econometric Analysis}

Descriptive statistical analysis was used to define mean, mode, percentage and standard deviation. Econometric analysis was employed to identify factors affection household choice of pastoralists to take part in cattle market. The data collected was analyzed using Statistical Package for Social Science (SPSS) version 20, STATA version 10 and Excel 2007 after editing, coding and the raw data collected from survey. 


\section{Results and Discussions}

This chapter presents the results of both the descriptive and econometric analysis. The first section deals with the socioeconomic characteristics of producers and traders. The second section looks into the econometric analysis. In the third part of the chapter is about market system in the district.

\section{Socio-Economic characteristics of pastoralists}

This section presents the socioeconomic characteristics of sample households in the area. The socioeconomic characteristics looked in to in the survey duration comprised of age, family size and years of schooling (Table 1).

Age Distribution of pastoralist Households: The average age of the Pastoralists household head was 42 . However, it ranges in between 20 and 81 . The proportion of sampled producers whose age lies in the range between 20 and 65 was $96.9 \%$. The remaining 3.1\% sampled pastoralists were aged more than 65 years. This findings show that majority the cattle producers were in the age range of active labor force and only few known to be dependant age category. Thus, this is very important with respect to the quantity supply of cattle and household market participation decision. The study is not in line with Desta et al. [10] result that states roughly three-quarters of pastoral households are of working age.

Table 1: Socioeconomic characteristics of producers $(\mathrm{N}=223)$.

\begin{tabular}{|c|c|c|c|c|}
\hline \multirow{2}{*}{$\begin{array}{c}\text { Socioeconomic } \\
\text { variables }\end{array}$} & \multicolumn{4}{|c|}{ Statistical Parameters } \\
\cline { 2 - 5 } & Mean & $\begin{array}{c}\text { Standard } \\
\text { Deviation }\end{array}$ & Minimum & Maximum \\
\hline Age & 42 & 12 & 20 & 81 \\
\hline Family size & 7 & 3 & 2 & 25 \\
\hline Years of schooling & 1 & 2 & 0 & 10 \\
\hline
\end{tabular}

Family Size of Pastoral Households: The family size distribution (Table 1) shows that the average family size of Moyale pastoralists is 7 . However, the range of family size for sampled pastoralist is between 2 and 25. From whole sample households in the area, the proportion of households with family size of 2 to 3 family sizes are $9.4 \%, 4$ to 6 are $41.7 \%$, and 7 to 10 are $41.3 \%$ and 11 to 25 are $7.6 \%$. The survey result reveals that majority of households belong to medium and large family size. The proportion of households with low and very high family size is few. The survey result is not agree with Tolossa et al. [8] result that stated the mean family size for pastoralist in Borana area was 8.

Education level of pastoral households heads $(\mathrm{N}=223)$ : The result in the Table 2 revealed that $81.2 \%$ of sampled households did not attend formal education, whereas; the proportion of pastoralist household who attended formal education (attended from primary grade to high school) was $18.8 \%$. The distribution of pastoralist households with respect to formal education attendance shows that less than one fifth they attended formal education. The study is not in line with
Tolossa et al. [8] where the proportion of producers attended formal education in which was $41.7 \%$.

Table 2: Family size of sampled producers.

\begin{tabular}{|c|c|c|c|}
\hline Group & $\begin{array}{c}\text { Producers } \\
\text { (N=223) }\end{array}$ & Percent & $\begin{array}{c}\text { Cumulative } \\
\text { Percent }\end{array}$ \\
\hline Low family size (2-3) & 21 & 9.4 & 9.4 \\
\hline Medium family size (4-6) & 93 & 41.7 & 51.1 \\
\hline Large family size (7-10) & 92 & 41.3 & 92.4 \\
\hline $\begin{array}{c}\text { Very large family size } \\
\text { (11-25) }\end{array}$ & 17 & 7.6 & 100 \\
\hline
\end{tabular}

\section{Socioeconomic characteristics of cattle traders}

Table 3: Education level of Pastoralist household head.

\begin{tabular}{|c|c|c|c|}
\hline $\begin{array}{c}\text { Category of } \\
\text { Education Level }\end{array}$ & Frequency & Percentage & $\begin{array}{c}\text { Cumulative } \\
\text { Percentage of } \\
\text { Respondent }\end{array}$ \\
\hline $\begin{array}{c}\text { Not attended Formal } \\
\text { education }\end{array}$ & 181 & $81.2 \%$ & $81.2 \%$ \\
\hline Primary school (1-4) & 18 & $8 \%$ & $89.2 \%$ \\
\hline $\begin{array}{c}\text { Secondary school } \\
\text { (5-8) }\end{array}$ & 20 & $9 \%$ & $98.2 \%$ \\
\hline High school (9-10) & 4 & $1.8 \%$ & $100 \%$ \\
\hline
\end{tabular}

Age structure of cattle traders: Table 3 revels that the mean age for cattle traders was 39.44 years. However, the age of sampled cattle trader in pastoralist's area ranges in between 23 and 60 . The study result confirmed that all the cattle traders are within the age bracket of active age category. This was an implication that almost all the traders are energetic enough to carry out cattle marketing activities. The survey results in Table 4 revealed that $36 \%$ cattle marketers were illiterate,20\% attended primary school (grade 1 to 4 ) and $36 \%$ attended junior school (grade 5 to 8 ) and $8 \%$ attended secondary high school (grade 9 up to 10) respectively.

Table 4: Socioeconomic characteristics of traders $(\mathrm{N}=25)$.

\begin{tabular}{|c|c|c|c|c|}
\hline \multirow{2}{*}{$\begin{array}{c}\text { Socioeconomic } \\
\text { Variables }\end{array}$} & Minimum & Maximum & Mean & $\begin{array}{c}\text { Std. Error } \\
\text { of Mean }\end{array}$ \\
\cline { 2 - 5 } & 0 & 10 & 3.6 & 0.69 \\
\hline Education level & 23 & 60 & 39.44 & 1.75 \\
\hline Age & 4 & 14 & 7.56 & 0.59 \\
\hline Family size & &
\end{tabular}

\section{Years of Schooling for traders}

Gender of Cattle Traders: The survey results revealed that all (100\%) cattle marketers were males. Since gender attributes the main criteria for determining entrance into cattle trade and thereby, it is advisable to consider gender mainstreaming.

Family size of cattle traders: The survey result shows that the average family sizes of cattle traders was 8 (Table 5). Regarding the distribution of persons per household, the result in the (Table 6) shows that, the majority of households have 4-6 persons (48\%) closely followed by those households with 
7-10 persons (40\%). But the proportion of households with very large family size (12-14 persons) is $12 \%$.

Table 5: Years of Schooling for traders

\begin{tabular}{|c|c|c|c|}
\hline $\begin{array}{c}\text { Category of Schooling } \\
\text { Years }\end{array}$ & Frequency & Percentage & $\begin{array}{c}\text { Cumulative } \\
\text { Percent }\end{array}$ \\
\hline $\begin{array}{c}\text { Not attended formal } \\
\text { education }\end{array}$ & 9 & $36 \%$ & $36 \%$ \\
\hline Primary school (1-4) & 5 & $20 \%$ & $56 \%$ \\
\hline Secondary school (5-8) & 9 & $36 \%$ & $92 \%$ \\
\hline High school (9-10) & 2 & $8 \%$ & $100 \%$ \\
\hline
\end{tabular}

Table 6: Family size of cattle traders.

\begin{tabular}{|c|c|c|c|}
\hline Group & $\begin{array}{c}\text { Frequency of } \\
\text { Traders (N=25) }\end{array}$ & Percent & $\begin{array}{c}\text { Cumulative } \\
\text { Percent }\end{array}$ \\
\hline Low family size (2-3) & 0 & 0 & 0 \\
\hline $\begin{array}{c}\text { Medium family size } \\
(4-6)\end{array}$ & 12 & $48 \%$ & $48 \%$ \\
\hline $\begin{array}{c}\text { Large family size } \\
(7-10)\end{array}$ & 10 & $40 \%$ & $88 \%$ \\
\hline $\begin{array}{c}\text { Very large family size } \\
(11-25)\end{array}$ & 3 & 12 & 100 \\
\hline
\end{tabular}

Factors affecting pastoralists Household's Choice of Cattle Market Participation: In order to estimate the market participation decision of pastoralists in the area, Logistic regression Model was employed by (STATA version 10) Here, the factors influencing the household's discrete choice behavior was modeled using a binary logistic model. Then binary logistic regression model allowed the estimation of a set of probabilities of market participation regimes for households with a given characteristic logit model where only one coefficient is estimated for all the outcomes. To investigate factors embedded in deciding cattle market participation, the following variables were used as explanatory variables: gender, education level, and other sources of income, household size and proximity to animal health center, number of camel owned, source of market information and accessibility of business support services. Similar to OLS regression, the prediction equation of Logistic regression model can be written as: $\log (\mathrm{p} / 1-\mathrm{p})=\mathrm{b} 0+\mathrm{b} 1{ }^{*}$ gender $+\mathrm{b} 2 *$ number of cattle owned $+b 3^{*}$ number of camel owned, where $p$ is the probability of cattle market participation. Expressed in terms of the variables used in this study, the logistic regression equation is $\log (p / 1-p)=-2.87+2.94 *$ gender $+.19 *$ number of cattle owned $+.20 *$ number of camel owned +error term. These estimates tell about the relationship between the independent variables and the dependent variable, where the dependent variable is on the logit scale. These estimates tell the amount of increase in the predicted log odds of cattle market participation = 1 that would be predicted by a 1 unit increase in the predictor, holding all other predictors constant. Because these coefficients are in log-odds units, they are often difficult to interpret, so they are converted into odds ratios.
The model specified for market participation:

$\mathrm{P}(\mathrm{y}=1 / \mathrm{x})=\mathrm{G}(\mathrm{Bo}+\mathrm{B} 1 \mathrm{x} 1+\mathrm{B} 2 \mathrm{x} 2+\mathrm{B} 3 \mathrm{X} 3+\mathrm{B} 4 \mathrm{x} 4--------\mathrm{BkXk})$ where $\mathrm{P}$ is probability of explanatory variable to affect market participation decision and $\mathrm{G}$ is a function taking on values strictly between zero and one: $0<\mathrm{G}(\mathrm{z})<1$, for all real numbers z. $Y i=$ the dependant variable this defines probability of market participation and $x i$ is explanatory variables. The independent variables defined as, $\mathrm{X} 1=$ gender of respondent, $\mathrm{X} 2=$ number of camel owned, $\mathrm{X} 3=$ market information source, $\mathrm{X} 4=$ distance in $\mathrm{km}$ between pastoralist home and animal health center, $Y=1$ when the household participated in market and $Y=0$ Otherwise.

$P(y=1 / x)=G$ (gender, cattleowned, camel owned,animalhealth center distance, cattle market information source, lagged price

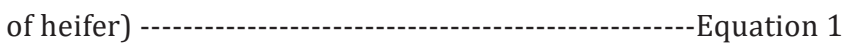

In short, the logistic regression model for market participation decision can be written as:

$\log (p / 1-p)=b 0+b 1 *$ gender $+b 2 *$ cattle owned + b3*camel owned------------------Equation 2

Gender: The coefficient for the variable gender is 1.071 . Because these coefficients are in log-odds units, they are not as such simple to interpret, so it is converted into odds ratios. The log odds units are converted in odds ration by taking exponentiation of the coefficient manually and excel sheet. As the result, odds ration coefficient for gender=Exp (1.071454) $=2.919622$. This is the proportional odds ratio of comparing male to females on cattle market participation given the other variables in the model are held constant. For males, the odds of market participation decision 2.919622 times higher than for female, given the other variables are held constant. This is to mean that being male increase probability decision of cattle market participation by the probability about 2.92 units as compared to females.

Number of cattle owned: the parameter estimate for the variable cattle owned is 0.1935 . This implies that for one unit increase in cattle owned, we expect 0.1935 increase in the logodds of dependent variable termed market participation, holding all other explanatory variables constant. The size of cattle reared by pastoralists is not only the variable that positively affects cattle market participation; it also affects number of cattle supplied. As the herd size increases, the probability of pastoral household to take part in cattle market increases while the probability of non-participation in cattle market decreases. This finding is also agrees with Asfaw and Jabbar [11] and Barrett et al. [3] that states the households with larger herd size has higher ability to generate surplus animals and are therefore more likely to sell. The implication is that active cattle markets depend on pastoralists attaining and maintaining sufficiently large herd sizes that they become willing to liquidate animals through the market.

Number of camel owned: The coefficient for the variable cattle owned is 0.2031 . This indicates that for one unit increase 
in camel owned, we expect 0.2031 increase in the log-odds of dependent variable termed market participation, holding all other explanatory variables constant. Total size of camel the respondent owned, is continuous variable and the sign is positive. The positive coefficients of parameter estimate implies that the pastoralists' household having one more additional camel have the more higher probability to participate in the cattle market. Due to wealth difference over pastoralists households, the household that had more camel have also more cattle, the probability of market precipitation increased with camel size. As the result households that owned one more camel have more likelihood of cattle participation. In addition to this, as climate

\section{Marketing System in the district}

Table 7: Determinants of cattle market participation by pastoral households.

\begin{tabular}{|c|c|c|c|c|c|}
\hline Explanatory Variables & Coefficient & Std. Err. & $\mathbf{z}$ & $P>|z|$ & Odds Ratio \\
\hline Constant & -2.87 & .67 & -4.30 & 0.000 & 0.06 \\
\hline gender & 1.07 & .41 & 2.64 & 0.008 & 2.92 \\
\hline cattle own & .19 & .04 & 5.41 & 0.000 & 0.19 \\
\hline Camel owned & .20 & .09 & 2.16 & 0.031 & 0.20 \\
\hline mktinfo1 & -.19 & .17 & -1.17 & 0.242 & 0.82 \\
\hline Distance to Animal health center & .15 & .10 & 1.54 & 0.124 & 0.15 \\
\hline Business support service & .30 & .38 & 0.80 & 0.422 & 1.35 \\
\hline Summary & Observation $=221$ & LR chi2 $=92.44$ & & \multicolumn{2}{|c|}{ Pseudo R2 $=0.3250$} \\
\hline
\end{tabular}

Source: own survey 2014.

Major Cattle marketing seasons and occasions in Pastoralist Area: Table 7 illustrates that cattle selling seasons identified by pastoralists in the area are dry season for about $40.4 \%$ households, wet season for $8.5 \%$ pastoralists and holidays for about $8.5 \%$ respondent households. The other $15.7 \%$ sampled households usually sell at combination of wet season, dry season and holidays. The remaining 26.9 sampled households sell their cattle in holidays and dry seasons. This implies that institution and climate variability has such a great role in cattle selling and market participation decision in pastoralist's households. As of interviewed pastoral households respondents confirmation in the area, usual buying seasons and occasion of cattle are dry season for $44.8 \%$ respondents, wet seasons for $13 \%$ households and holidays for $4.9 \%$ respondents accordingly. The proportion of pastoralists buy cattle in wet season, dry season and holidays is $14.3 \%$ and that buy in both holidays and dry season equals $22.9 \%$ respectively. Even if the proportion of cattle bought at wet season overrides sold, the survey result justified that major cattle selling season are also cattle buying months for pastoral households in the area. The major seasons of cattle marketing identified in the area are based on weather variable wet season, dry season and holidays based on marketing occasions. As result, the study result suggests that the major cattle marketing season skewed toward climate variability especially toward dry season. Change in weather condition understood as one of the important variable that forces the pastoralist household to take part in cattle market and cattle supply to market. Getachew et adaptation strategy, pastoralists in the study districts has been changing production from cattle to camel there by increasing the camel herd and in opposite decrease the cattle by being participated in cattle market. This study is also supported by other finding Kelemework [12] that states pastoralists have long developed adaptive strategies against environmental shocks through effective management of their resources. Adaptive strategies include the establishment of strong economic and social support networks, herd splitting, and herd diversification. Thus, for a one unit increase in number of camel owned, the odds of market participation 1.225168 times greater, given the other variables are held constant in the model. al. [2] also observed that cattle markets are characterized by seasonality in flow and prices of animals. Shifts in supply could occur as a result of factors including seasonality of consumption demand in domestic and export markets, drought, disease outbreak, lack of information, availability of food aid, clan conflicts and others 2008. Awuor [3] concluded that the volume of livestock traded and pastoralists' willingness to market dependents on the availability of pasture and water and rainfall variability. Pastoralists are reluctant to sell their animals during the wet period when pastures rejuvenate and the animals return to milk production. But expectations of prolonged dry spells and outbreaks of disease increase the supply of livestock to the market. The off take rates for livestock during drought were estimated to be about twofold the off take rates during a normal year.

\section{a. Months of Cattle selling}

b. The Figure 1 above points out that the major cattle selling months in study area is highly linked with festivals or holidays (informal institution), seasons (dry and wet seasons) and related household cash need. From Figure 1 above, cattle selling in September, January and June are the top season of marketing that are known dry season in the area. As the study result indicates the double festival in September, dearth period around January and June inflated cattle selling frequency. This study result agrees with other finding of (MOA,2013) that stated cattle supply and demand are heavily influenced by the season of the year and the 
occurrence of religious and cultural festivals, as well as availability of feed which drives sales during the dry season.

c. Figure 2 point outs that the producers purchase cattle throughout the year. However, there was variation in level and frequency of cattle bought across months. The proportion of cattle bought around April (first rainy season) was the major purchasing months that followed by second rainy season around October. The proportion of cattle bought around February (first dry season) was the lowest followed by the August (second dry season).

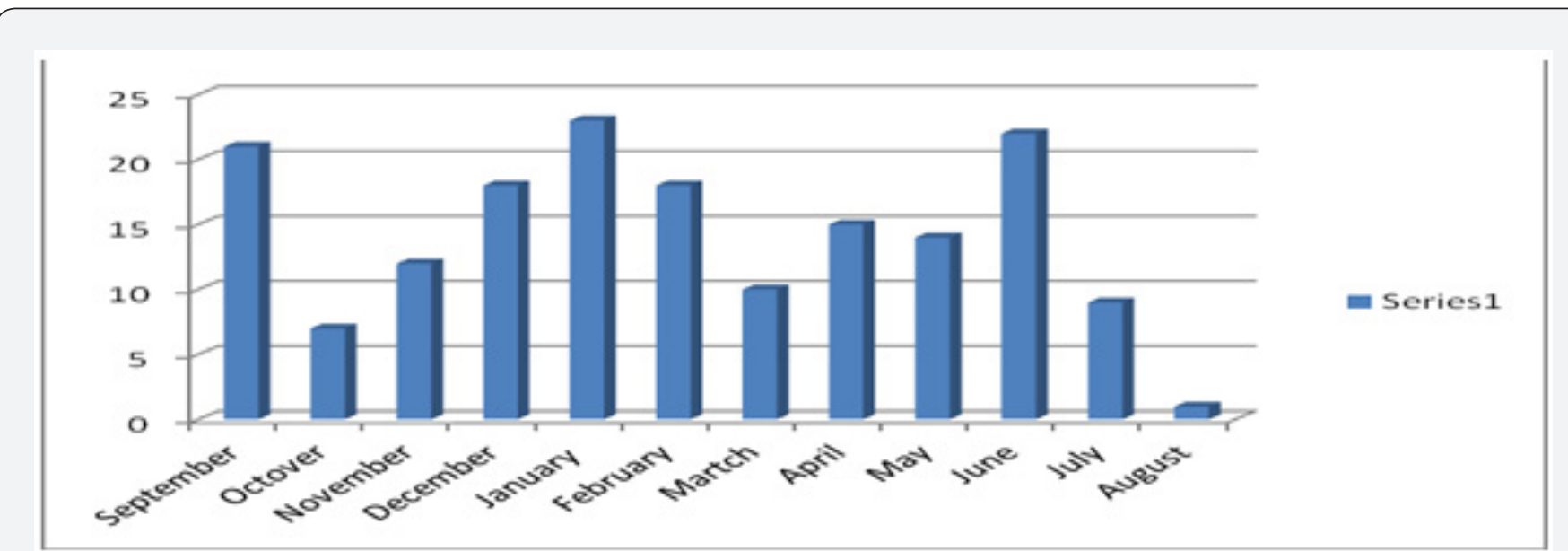

Figure 1: Months of Cattle selling.

Source: own survey

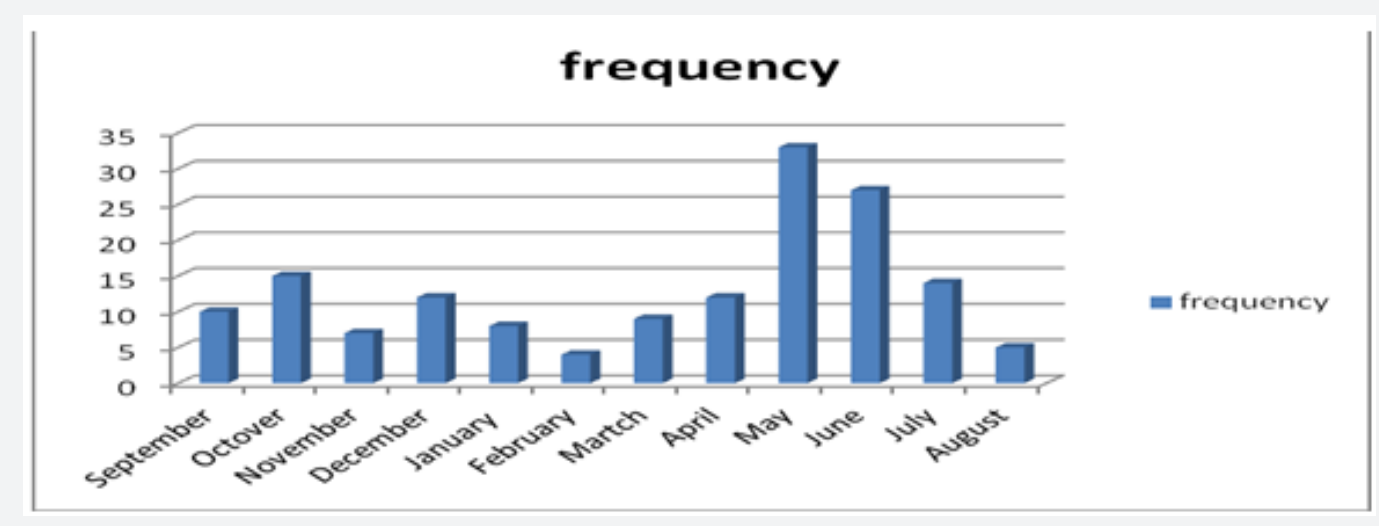

Figure 2: Months of Cattle buying.

Source: own survey

d. Amount of income earned by brokers by facilitating cattle marketing process

e. The broker in cattle market confirmed that they collect different level of income from different cattle type. The mean income earned by broker by facilitating ox, cow, bull, heifer and calves was 75.00, 72.86, 65.71, 58.58 and 43.57 respectively. Table 8 presents amount of income earned by broker.

Table 8: Cattle marketing seasons and occasions in Pastoralist Area.

\begin{tabular}{|c|c|c|c|c|c|}
\hline Cattle Selling Seasons & Frequency & Percentage & Cattle Buying Seasons & Frequency & Percentage \\
\hline dry season & 90 & 40.4 & dry season & 100 & 44.8 \\
\hline wet season & 19 & 8.5 & wet season & 29 & 13.0 \\
\hline holidays or festivals & 19 & 8.5 & holidays or festivals & 11 & 4.9 \\
\hline holidays, dry season and wet season & 35 & 15.7 & holidays, dry season and wet season & 32 & 14.3 \\
\hline holidays and dry season & 60 & 26.9 & holidays and dry season & 51 & 22.9 \\
\hline
\end{tabular}

f. Table 9 explains the large proportion of brokers obtained income from ox marketing process ranged in between 50 and 70 (42.8\%), followed by 20 and 40 (28.6\%) and 80 and 100 (21.4\%). The remaining 7.1 percent of brokers collected income more than 100 Birr per ox. The range of income earned by brokers from cow market process 
was 20 to 40 (28.6\%), 50 to 60 (50\%), 80 to 100 (14.3\%) and more than 100 Birr (7.1\%) accordingly. The large proportion of income earned by brokers range from bull was 50 to 70 (50\%) that followed by 20 to 40 (28.6\%), 80 to $100(14.3 \%)$ and more than 100 Birr (7.1\%). Majority of brokers collected income from heifer in the range between 50 to 70 (50\%), that loosely followed by 20 to 40 (28.6\%) and 80 to 100 (21.4\%). The income earned by brokers from calve marketing activity lied in the range between 20 to 40 (50\%) and 50 to 70 (50\%). This study implied that almost all income earned by brokers from various cattle category skewed toward 50Birr.

Table 9: Amount of brokers' income from market process ( $\mathrm{N}=14)$.

\begin{tabular}{|c|c|c|c|c|}
\hline \multirow{2}{*}{ Cattle Type } & \multicolumn{4}{|c|}{ Statistical Parameters } \\
\cline { 2 - 5 } & Minimum & Maximum & Mean & $\begin{array}{c}\text { Std. } \\
\text { Deviation }\end{array}$ \\
\hline Ox & 20 & 200 & 75.00 & 68.69 \\
\hline Cow & 20 & 300 & 72.86 & 68.99 \\
\hline Bull & 20 & 200 & 65.71 & 44.50 \\
\hline Heifer & 20 & 100 & 58.58 & 25.07 \\
\hline Calves & 20 & 60 & 43.57 & 10.08 \\
\hline
\end{tabular}

Source: household survey

g. The brokers in pastoralist area obtain different level of income from different market actors. The survey study indicated that broker collect payment for role they play in cattle marketing process from both seller and buyer. An average income collected by brokers in the area from producers was 47 and 96 Birr trader. Minimum amount of payment from producer was 20Birr and maximum income was 80Birr. The minimum and maximum payment from trader was about 50 and 250 Birr respectively. This study result confirmed that brokers collect income from both seller and buyer, but in different amount.

h. Among the interviewed brokers 64\% perform their activity in collaboration with other brokers and the remaining 36\% undertake the activity individually. Similar to other business activity in the area, the brokering activity faced some sorts of conflicts with other stakeholders in the marketing process. The proportion of brokers faced conflicts with other stakeholders in the area amounts to $86 \%$ and that did not $14 \%$. Some of major cattle marketing actors that had conflicts with broker mostly were other brokers for $42 \%$, pastoralists for $33 \%$, and trader for $25 \%$ accordingly. The brokers used different sorts of conflict resolution techniques that rose between market actors. It was reported that $83 \%$ of respondents' brokers resolve conflicts by having their own customer buyer and seller and 17\% used elders from the area that could be traders, brokers and pastoralists as well.

i. Responsible Household member of Cattle marketing.

j. The function of households in cattle market chain of pastoralist's area is different for various households' members. Major reasons for participation of different household members in different cattle market activity listed are institutional related reasons and works division. The institutional related factors such as gender, personality, holidays and similar issues had such an influence in cattle market chain dynamics. As the result institution was responsible for $56 \%$ pastoralist cattle marketing and $46 \%$ marketing activity accomplished in relation to work division. Form interviewed pastoralists 56\% households performed by husbands only, $3 \%$ performed by Wife, $35 \%$ performed by anybody who owns the cattle and $6 \%$ performed by both husband and wife.

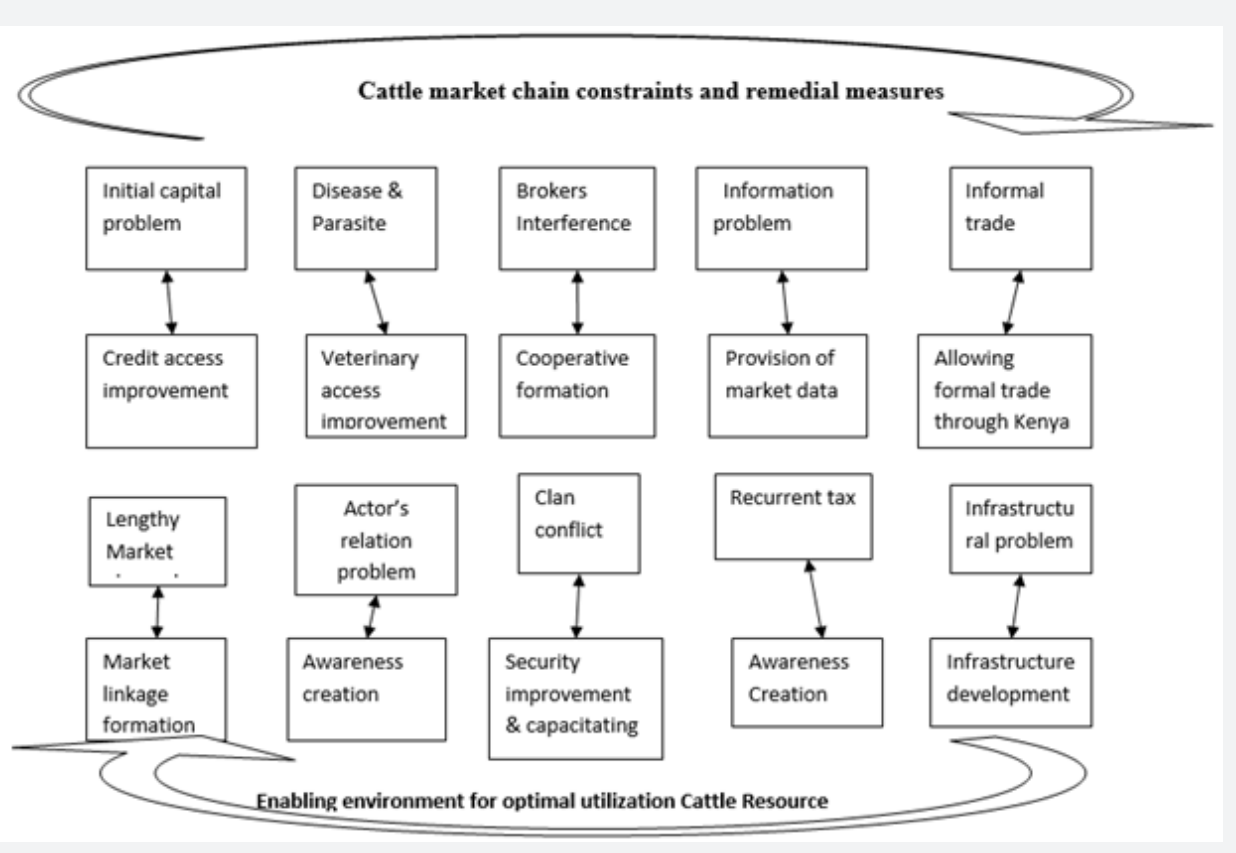

Figure 3 
k. The cattle marketing activity as any business activity was performed by community in the area by different household members. Important factors that influence carrying out cattle marketing activity listed were the institutional matter and work division. From the influential factors institutional matter highly important over marketing of cattle in the area than work division and it was assured by $56 \%$ of interviewed households and the remaining $44 \%$ households under take cattle market based on work division of the household member. The proportion of respondents confirmed was $56 \%$ for husband, $3 \%$ for wife, $35 \%$ anybody who owns the cattle and $6 \%$ for Husband in line with wife accordingly $[12,13]$.

\section{Conclusion}

Regression analysis confirms that greater cattle and camel holdings results in greater cattle market participation and it also has a positive impact upon household choice of market participation. The key practical implication is that active cattle markets depend on pastoralists attaining and maintaining sufficiently large herd sizes of cattle and cattle that make them willing to liquidate animals through the market. It is generally believed that pastoralists sell their animals at least partly in response to demand for cash to meet expenditure needs. Relatively wealthy pastoralists, with greater herd size, have considerably higher expenditure rates and thus use cattle markets more frequently to cash out animals. This study result also pointed out that destocking is not solution for production and productivity optimization, rather Cattle breed conservation promotion. It is also justified that quantity is believed to bear quality. The major market constraints sorted out by market actors include lengthy market channel, brokers interference, disease and parasite, clan conflicts and unfriendly relation between market actors, illegal trade, lack of reliable market information, recurrent tax, infrastructure problem and initial capital shortage. This calls for systematic government intervention that supposed to optimize the cattle production productivity and ease characterized constraints through cooperative formation, market and market route searching, updating market information, capacity building, linking producers to market, adopting value addition tools and integrated approaches of different stakeholders.

\section{References}

1. Barrett CB, McPeak, John G, Luseno Winnie, Little PD (2004) Pastoralist Livestock Marketing Behavior in Northern Kenya and Southern Ethiopia: An Analysis of Constraints Limiting Off-take Rates. Economics Faculty Scholarship. p 84.

2. Getachew Legese, Hailemariam Teklewold, Dawit Alemu, Asfaw Negassa (2008) Live animal and meat export value chains for selected areas in Ethiopia: Constraints and opportunities for enhancing meat exports. Ethiopian Institute of Agricultural Research (EIAR). International Livestock Research Institute (ILRI), Addis Ababa, Ethiopia p.66.

3. Awuor T (2007) Review of Trade and Markets Relevant to Food Security in the Greater Horn of Africa. A special report by the Famine Early Warning Systems Network (FEWS NET), United States Agency for International Development p.50.

4. Wassie Berhanua, Bichaka Fayissab (2010) Analysis of the Household Economy and Expenditure Patterns of a Traditional Pastoralist Society in Southern Ethiopia, Department of Economics and Finance working paper series.

5. Niguse Bekele (2008) Ecological Impacts of Bush Encroachment on Rangeland Ecosystem: The Case of Hallona and Medhacho Pastoralist Associations in Borana Lowlands.

6. Beyene Teklu, Yibeltal Tebikew (2014) Implications of Constrained Mobility on Livestock Production and Pastoral Livelihoods of Borana Plateau, Southern Ethiopia. Feed the Future Innovation Lab for Collaborative Research on Adapting Livestock Systems to Climate Change. Colorado State University, USA; Wageningen University, Netherlands and Hawassa University, Wondo Genet College of Forestry and Natural Resources, Wondogenet, Ethiopia p.6.

7. CSA (Central Statistical Agency) 2012/13 (2005 EC) Report on Livestock and Livestock Characteristics (Private Peasant Holdings). Federal Democratic Republic of Ethiopia, Agricultural Sample Survey, Volume II, Addis Ababa. Ethiopia pp.188.

8. Tollossa Worku, Edessa Negerra, Ajebu Nurfeta, Haile Welearegay (2014) Milk Handling Practices and its Challenges in Borena Zone Pastoral Community. Ministry of Education, Borana Zone, Oromiya Regional State, Hawassa University Faculty of natural Science, Department of Biology, College of Agriculture, School of Range and Animal Science, Hawassa, Ethiopia. African Journal of Agricultural Research 9(14): 1-8.

9. Yount Rick (2006) Research Design and Statistical Analysis for Christian Ministry ( $4^{\text {th }}$ edn.). Southwestern Baptist Theological Seminary and to the members of the North American Professors of Christian Education Association (NAPCE). USA pp.500.

10. Desta S, Tezera S, Gebru G, Kristjanson P (2011) Summary of Baseline Household Survey Results: Borana, Ethiopia. CGIAR Research Program on Climate Change, Agriculture and Food Security (CCAFS). Copenhagen, Denmark p.33.

11. Asfaw Negassa, Jabbar M (2008) Livestock ownership, commercial offtake rates and their determinants in Ethiopia. Research Report 9. ILRI (International Livestock Research Institute), Nairobi, Kenya. p.52.

12. Kelemework Tafere (2012) Pastoralism at Crossroads: Changing Features of Climate, Livelihood and Social Organization in East Africa. Mekelle University, Mekele, Ethiopia. Global Journal of Human Social Science: C Sociology, Economics \& Political Science Global Journals Inc, (USA) 9(12): 1-5.

13. MOA (Ministry of Agriculture) and Norman Borlaug Institute for International Agriculture. AGP-Livestock Market Development Project (2013) Livestock Market Development End Market Analysis for Meat/ Live Animals, Leather and Leather Products, Dairy Products Value Chains. Addis Ababa, Ethiopia. 
Your next submission with Juniper Publishers will reach you the below assets

- Quality Editorial service

- Swift Peer Review

- Reprints availability

- E-prints Service

- Manuscript Podcast for convenient understanding

- Global attainment for your research

- Manuscript accessibility in different formats ( Pdf, E-pub, Full Text, Audio)

- Unceasing customer service

Track the below URL for one-step submission https://juniperpublishers.com/online-submission.php 